УДК 330.16.22(11)

DOI: https://doi.org/10.32782/2415-8801/2020-6.12

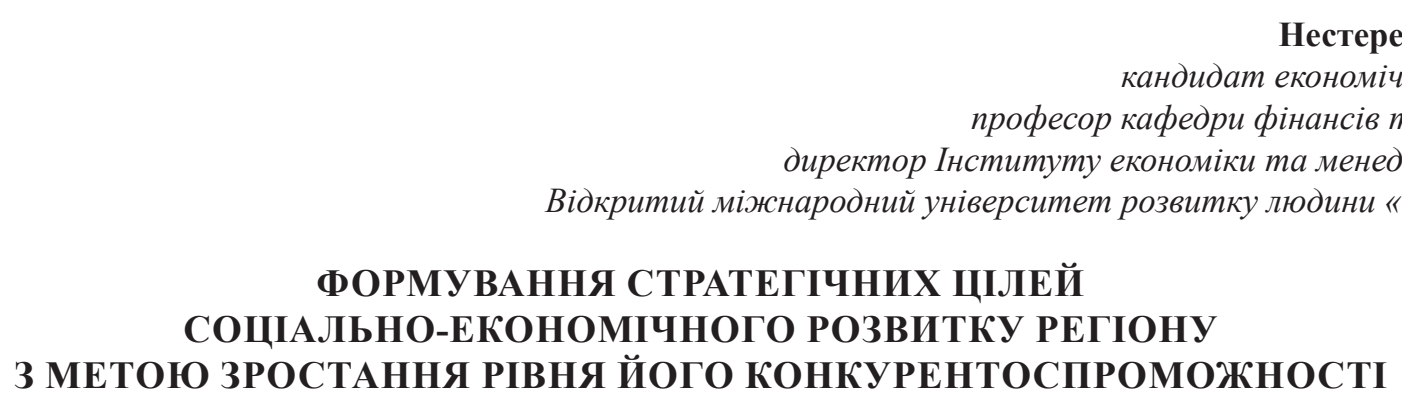

Устатті було обтрунтовано ізмістовнорозкритологічнусхемурозробки науково обгрунтованихстратегічних цілей комплексного соціально-економічного розвитку регіону. Запропонована схема, дозволяє роздлядати поняття мети як сукупність якісних і кількісних характеристик об'єкта цілепокладання; враховує складну структуру об'єкта цілепокладання - регіональної соціально-економічної системи, ццо базується на наукових принципах, які враховують обгрунтований наукових підхід до формування стратегічних цілей регіонального розвитку, а такожс специфіку об'єкта цілепокладання. Були розроблені методичні пропозиції щцодо формування системи стратегічних цільових установок (СЦУ) комплексного соціально-економічного розвитку регіону як ключового етапу формування стратегічних цілей регіонального розвитку та зростання конкурентоспроможності, в тому числі: запропонована принциова схема розробки СЦУ розвитку регіону, що базується на логіці стратегічного територіального планування.

Ключові слова: стратегічні иільові установки, регіон, розвиток регіону, конкурентоспроможність, показники розвитку, етапи формування цілей.

\title{
FORMATION OF STRATEGIC GOALS \\ OF SOCIO-ECONOMIC DEVELOPMENT OF THE REGION \\ WITH THE PURPOSE OF GROWING THE LEVEL OF ITS COMPETITIVENESS
}

\section{Nesterenko Svitlana \\ Open International University of Human Development «Ukraine»}

The article substantiates the internal and external attributes of the process of forming and implementing the strategic goals of the socio-economic development of the region, which determine the structure, content and logic of the process of forming and implementing the strategic goals of regional development. The noted attributes are considered as requirements that must be met by scientifically grounded goals of the socio-economic development of the region. The application of a systematic approach to goal-setting at the regional level is due to the need to describe the region as a complex, open, hierarchically structured and purposefully developing system with heterogeneous elements of living conditions. The logical 
scheme for the development of scientifically grounded strategic goals of the integrated socio-economic development of the region was substantiated and substantively revealed. The proposed scheme allows us to consider the concept of a goal as a set of qualitative and quantitative characteristics of the goal-setting object; takes into account the complex structure of the goal setting object - the regional socio-economic system; is based on scientific principles that take into account a sound scientific approach to the formation of strategic goals for regional development, as well as the specifics of the goal-setting object. Methodological proposals were developed for the formation of a system of strategic target settings (STS) for the integrated socio-economic development of the region as a key stage in the formation of strategic goals for regional development, including: proposed a conceptual scheme for the development of STS for the development of the region, based on the logic of strategic territorial planning; substantiated the requirements for the information support of the process of forming the STS in the context of the main stages of their development; the structure of the tree of strategic targets is proposed, which takes into account the specifics of the regional socio-economic system and allows to form a system of strategic targets for the integrated socio-economic development of the region.

Keywords: strategic goals of the installation, region, development of the region, competitiveness, indicators of development, stage of formulation of goals.

Постановка проблеми. Управління територією передбачає вирішення питань про напрямки ії розвитку, які визначаються системою відповідних цілей. Як відомо, якісно організована система управління буде ефективно виконувати свої функції тільки за умови чіткого розуміння цілей розвитку, здатних мотивувати діяльність системи і формувати іiі конкурентоспроможність. Це положення застосовується і до управління такою складною соціально-економічною системою як регіон. Відсутність чітко виражених стратегічних цілей розвитку регіону призводить до негативних наслідків - від неефективного використання наявних ресурсів, зниження рівня добробуту населення до ситуації, коли напрямки розвитку регіону повністю диктують зовнішні суб' єкти впливу, зацікавлені у використанні його потенціалу в своїх інтересах. Відповідно соціально-економічний розвиток регіону багато в чому залежить від того, наскільки чітко визначені стратегічні цілі цього розвитку, правильно поставлені і структуровані завдання, наскільки раціонально використовуються ресурси для їх вирішення. Саме тому проблеми, пов'язані з науковим забезпеченням формування стратегічних цілей розвитку регіону для підвищення його майбутнього рівня конкурентоспроможності, є принципово важливими.

Аналіз останніх досліджень і публікацій. Питання становлення теоретичних i практичних основ цілепокладання в межах стратегічного розвитку регіонів широко викладені в наукових роботах таких авторів як: В. Геєць [1], І. Грищенко [4], Я. Жаліло [9], О. Жихор [6], О. Качний [2], Б. Кліяненко [5], В. Кравців, Н. Манн [3]

В той же час, потребують вдосконалення методичні підходи щодо формування стратегічних цілей соціально-економічного розвитку регіонів.

Постановка завдання. Метою дослідження є розробка методичного підходу щодо формування цілей і етапів регіонального розвитку в межах довготермінової стратегії зростання загального рівня конкурентоспроможності регіону.

Виклад основного матеріалу дослідження. Очевидним $є$ той факт, що формування цілей регіонального розвитку - це досить складне завдання, що вимагає глибоких знань у багатьох областях науки. Як зазначає Геєць В.М. [1, с. 45], процес формування цілей (власне цілепокладання) являє собою логічну процедуру, яку можна тільки систематизувати, але не формалізувати. Спираючись на вимоги до наукового цілепокладання, нами запропонована логічна схема формування стратегічних цілей комплексного соціально-економічного розвитку регіону (рис. 1), що включає наступну послідовність етапів.

I Етап. Аналіз і прогноз соціально-економічного розвитку регіону. Що стосується завданням аналізу i прогнозу соціально-економічного розвитку регіону 3 метою зростання конкурентоспроможності, на наш погляд, необхідно керуватися такими основними вимогами:

- комплексність оцінки, що забезпечує врахування всіх найважливіших аспектів соціально-економічного становища регіону;

- системність оцінки, що передбачає аналіз кожної проблеми у всій іiі повноті і у всіх іiї взаємозв'язках;

- забезпечення максимальної репрезентативності показників для оцінки різних аспектів соціально-економічного становища регіону;

- адаптація системи використовуваних показників до можливостей існуючої статистичної звітності 3 пріоритетною орієнтацією на методи автоматизованої обробки вихідних даних;

- максимальна відповідність системи показників завданням прогнозування соціального і економічного розвитку регіону;

- забезпечення максимальної інформативності вихідних результатів оцінки соціально-економічного становища регіону з позицій прийняття адекватних рішень на регіональному рівні щодо формування конкурентоспроможності.

Як показав аналіз практики постановки цілей соціально-економічного розвитку регіону, аналіз його соціально-економічного розвитку має проводитись за наступними напрямками:

- аналіз показників соціально-економічного розвитку регіону і виявлення проблем;

- аналіз внутрішніх закономірностей розвитку регіону;

- аналіз впливу зовнішніх факторів, що визначають розвиток регіону, що включає: оцінку регіональної політики в бюджетно-податкової, грошово-кредитної, інвестиційної, зовнішньоекономічної сферах;

- аналіз стану і проблем єдиного правового і організаційно-економічного простору країни; аналіз стану національної економіки в цілому (по зростанню ВВП, темпів інфляції, рівня зайнятості тощо); країні;

- оцінку рівня стабільності політичної ситуації в

- аналіз соціально-економічного потенціалу регіону, що включає оцінку внутрішніх ресурсних можливостей і обмежень, що існують в регіоні, в тому числі 


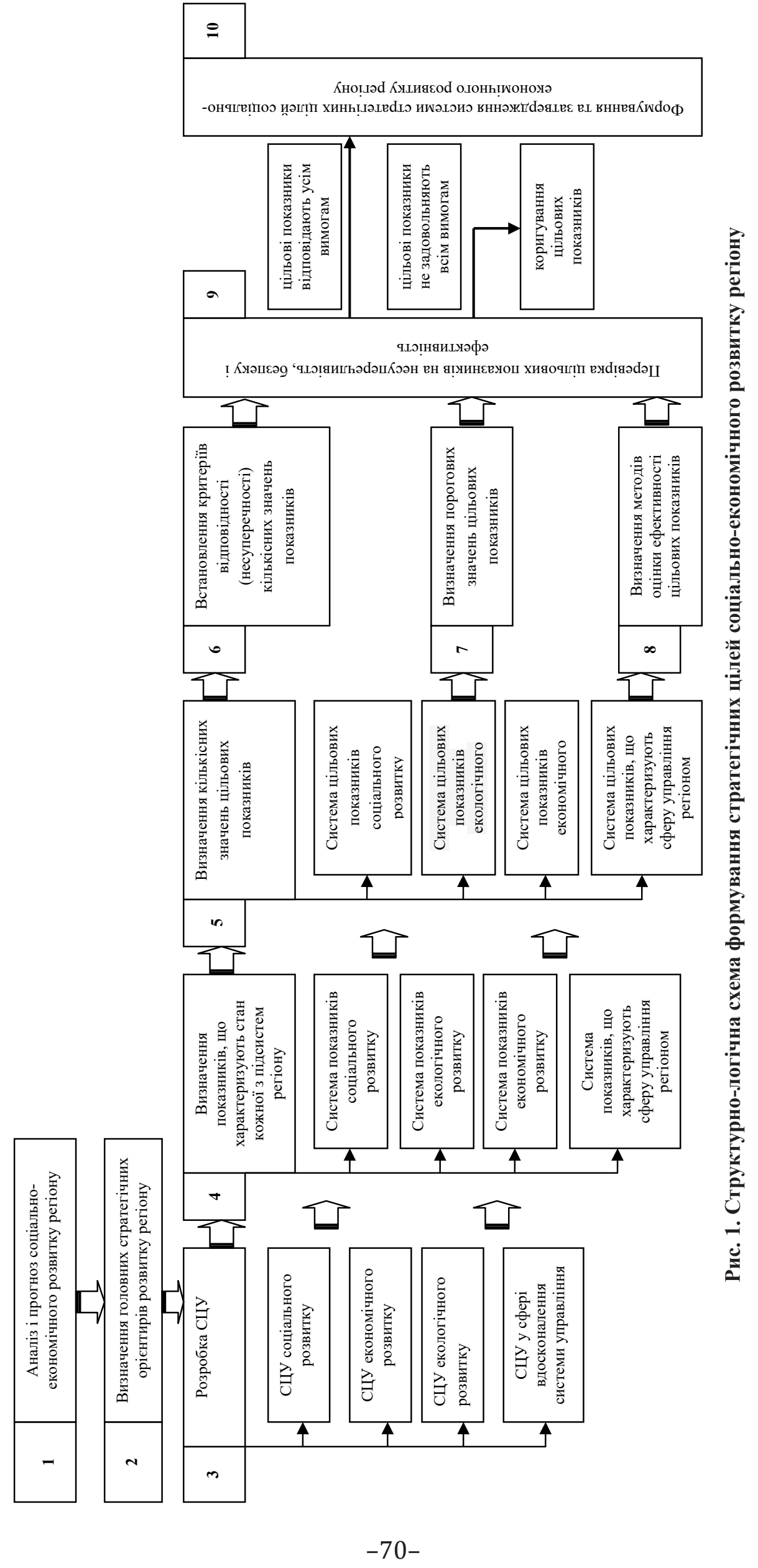


природно-ресурсного потенціалу, розмірів капіталу і стану виробничої інфраструктури, розмірів трудового потенціалу, стану фінансової системи регіону, його науково-технічного потенціалу, а також можливостей залучення необхідних ресурсів ззовні;

- інтегральна оцінка соціально-економічної ситуації в регіоні $[2 ; 3]$.

II Етап. Формування основних стратегічних орієнтирів розвитку регіону. На наш погляд, стратегічні орієнтири розвитку регіону повинні відповідати таким вимогам:

- стратегічні орієнтири розвитку регіону не повинні повністю залежати від поточного функціонування регіональної системи, а повинні бути орієнтовані в майбутнє, визначати основу для розробки стратегії розвитку;

- стратегічні орієнтири розвитку регіону повинні забезпечувати основу для визначення ключових цілей по всіх підсистем регіону (соціальної, екологічної, економічної, підсистеми управління);

- стратегічні орієнтири повинні характеризувати необхідний стан розвитку регіону на певні моменти часу [4].

III Етап. Формування системи стратегічних цільових установок соціально-економічного розвитку регіону. Зміст третього етапу полягає в розробці та обгрунтуванні системи стратегічних цільових установок соціально-економічного розвитку регіону і виявлення найбільш важливих, пріоритетних проблем, включаючи їх класифікацію, узагальнення і ранжування. Таким чином, на вербальному рівні формуються цільові установки в розрізі підсистем регіону, тобто цільові установки соціального, екологічного, економічного розвитку, а також цільові установки сфери управління.

IV Етап. Визначення показників, що характеризують стан кожної з підсистем регіону. На даному етапі визначається система показників для повної кількісної характеристики цільових установок. При виборі показників розвитку слід враховувати, що окремі показники повинні бути логічно пов'язані між собою, тобто слід говорити не про набір, а про систему показників.

У загальному випадку система показників повинна давати узагальнюючу оцінку соціальних параметрів регіону (включаючи демографічні, параметри, що відображають умови життя, праці і побуту населення регіону); характеризувати в цілому об'єктивні економічні (виробничі) умови регіону, а також відображати соціальні характеристики позавиробничої сфери, залежні від розвитку виробництва. Слід зазначити, що при виборі системи показників, що описують досягнення соціально значущої мети - підвищення якості життя - важливо враховувати інтегрований характер поняття «якість життя» і пов'язувати в єдину систему, як показники рівня соціального розвитку, так і параметри економічного характеру [5].

Якість життя населення пропонується оцінювати за допомогою єдиного інтегрального показника, що включає весь комплекс потреб і інтересів людини. Найбільш повний перелік показників для оцінки якості життя населення міститься, на наш погляд, в роботі [6, с. 23-24]. Відповідно до даного підходу ми можемо виділити чотири базових індикатора, що визначають якість життя:
I. Демографічна ситуація: народжуваність і смертність, число шлюбів і розлучень, очікувана тривалість життя.

II. Добробут населення: показники рівня життя людини, що відображають ступінь задоволення його матеріальних i духовних потреб (заробітна плата, реальні доходи, їх диференціація, рівень споживання благ і послуг тощо).

III. Якість умов життєдіяльності населення: рівень умов праці, соціального захисту, фізичної і майнової безпеки члена суспільства, криміногенний та соціально-політичного здоров'я самого суспільства, рівень охорони здоров'я, культури тощо.

IV. Якість навколишнього середовища: дані про забруднення повітряного простору, грунтів і води.

Кожен з чотирьох базових індикаторів відображає умови, в рамках яких виникають процеси задоволення як біологічних, так і соціальних потреб членів суспільства. Індикатори складаються з показників, які узгоджуються зі статистичними даними. Серед них: очікувана тривалість життя при народженні, природний приріст населення, частка фахівців з вищою освітою, валовий регіональний продукт (ВРП) на душу населення, індекс споживчих цін, розмір середньомісячної заробітної плати, індекс концентрації доходів (коефіцієнт Джині), частка витрат на харчування в споживчих витратах населення, забезпеченість житлом [7]. 3 позиції вирішення проблеми формування системи цілей стратегічного соціально-економічного розвитку регіону конструктивної представляється угруповання показників на цільові (або цілеформуючі) і забезпечуючі.

V Етап. Визначення кількісних значень показників. Даний етап передбачає визначення кількісних значень показників (цільових нормативів), що характеризують перспективний стан кожної з підсистем регіону (економічної, соціальної, екологічної та сфери управління). Кількісне значення цільового показника показує рівень, до досягнення якого за поточної ситуації слід прагнути [8]. Логічна схема проведення аналітичних робіт з визначення кількісних значень показників представлена на рис. 2.

На першому етапі (блок 1) встановлюється динаміка змін показників по роках періоду, що передує прогнозованому. При цьому необхідно вибрати аналізований період, який буде мати $з$ прогнозованим періодом щодо загальний вектор розвитку.

На другому етапі (блок 2) в межах проведення інерційного прогнозу показників виконується екстраполяція часового ряду. Мета інерційного прогнозу - отримати оцінки значення показника в прогнозованому періоді, якщо не буде вноситися будь-які додаткові дії, що управляють в процес, тобто без виявлення резервів, розробки програмних заходів, їх реалізації. Можливо, що отримані значення показника будуть задовольняти вимогу необхідності, потрібного їх рівню. Проте в переважній більшості випадків цей рівень виявляється недостатнім і тим самим виявляється завдання його підвищення програмним методом як індикатора рішення економічної або соціальної проблеми.

На третьому етапі (блок 3) здійснюється інвестиційно-активний (цільової) прогноз. Цей прогноз заснований на сценарному методі визначення необхідного рівня показника виходячи з необхідності досягнення 


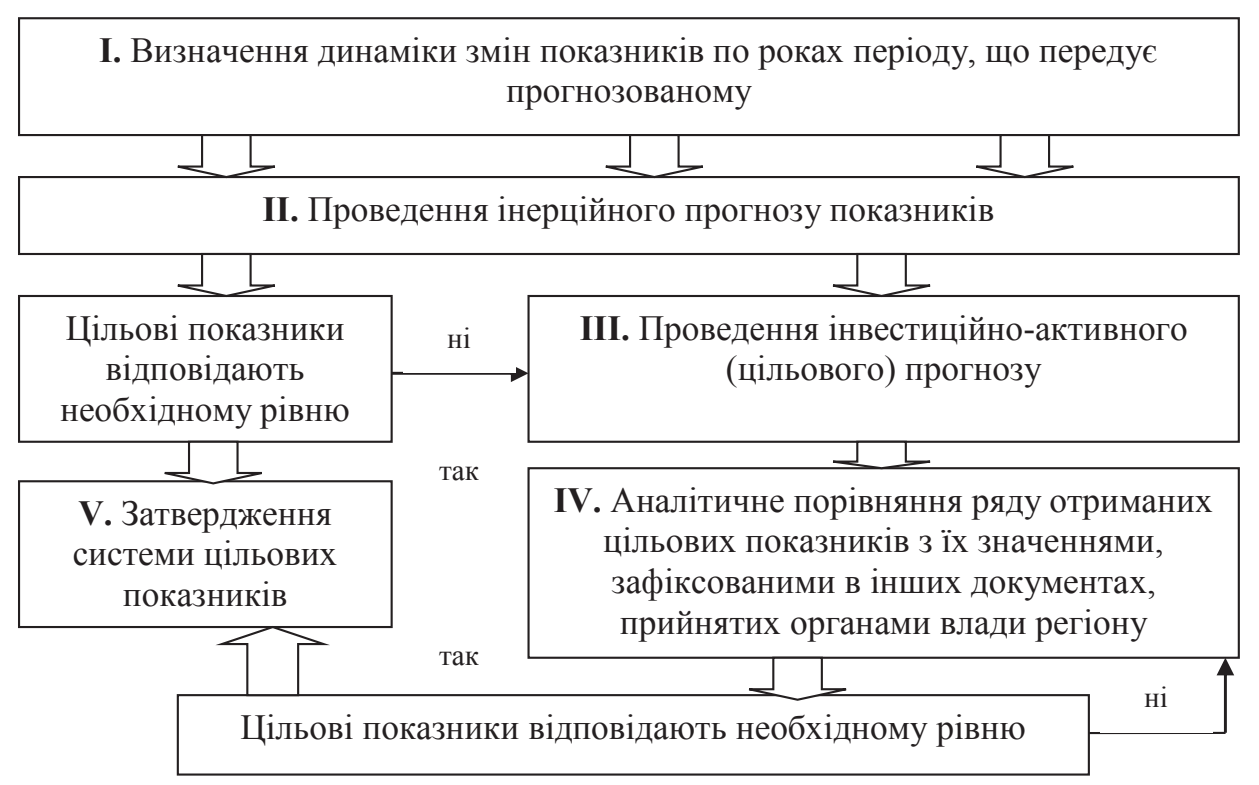

Рис. 2. Логічна схема визначення кількісних значень показників в рамках розробки програми соціально-економічного розвитку регіону

довгострокової мети, позначеної в концепції або стратегії розвитку регіону; аналізі чинників поліпшення показника і резервів використання в прогнозованому періоді; пропозицій складу програмних заходів по реалізації резервів 3 оцінкою необхідних інвестицій і їх джерел.

На четвертому етапі (блок 4) проводиться аналітичне порівняння ряду отриманих цільових показників 3 їх значеннями, зафіксованими в інших документах, прийнятих органами влади регіону. У разі, якщо отримані значення показника будуть задовольняти необхідному рівню, цільові показники затверджуються (блок 5).

VI Етап. Встановлення критеріїв відповідності (несуперечності) кількісних значень показників. В якості можливих прикладів суперечливих показників можна навести такі співвідношення:

- збільшення темпів економічного зростання i поліпшення соціальних показників (збільшення реальних грошових доходів населення, реальної середньомісячної заробітної плати);

- збільшення темпів зростання ВРП, індексу промислового виробництва і збільшення темпів зростання інвестицій;

- збільшення масштабів матеріального виробництва і поліпшення екологічної ситуації в регіоні, збільшення обсягів матеріального виробництва та підвищення рівня розвитку фінансово-кредитної інфраструктури [9].

Таким чином, в основу розробки системи критеріїв відповідності (несуперечності) показників, на нашу думку, повинен бути покладений відтворювальний підхід. Визначаючи кількісні значення показників, необхідно з'ясувати, який вплив вони будуть чинити на відтворення тих чи інших видів ресурсів регіону. Рішення даної задачі можливе на основі визначення пропорцій регіонального відтворювального процесу. Залежно від характеру між різними елементами відтворювального процесу ми виділяємо шість груп пропорцій (рис. 3).
VII Етап. Визначення порогових значень кількісних показників розвитку регіону. 3 уявлення про безпеку як про один з найважливіших умов життєдіяльності слід, що життєво важливі інтереси особистості, суспільства і держави повинні бути відповідним чином захищені. Таким чином, визначення критеріїв безпеки (в тому числі і в економічній сфері) представляється можливим на основі виявлення фактів наявності чи відсутності стану захищеності життєво важливих інтересів особистості, суспільства і держави. Представимо авторську послідовність виконання завдання з розробки системи порогових значень факторів, перевищення яких критично для безпечного розвитку регіону (рис. 4).

VIII Етап. Вибір і затвердження методів оцінки ефективності цільових показників. Сутність даного етапу полягає у виборі конкретного методу (методів) оцінки ефективності намічених цільових показників в розрізі основних підсистем регіону (соціальної, екологічної, економічної). Відомо, що «ефективність» - це відносна величина, яка відображає ставлення кінцевого результату процесу (програми, проекти) до витрат (ціни) по досягненню кінцевого результату.

IX Етап. передбачає проведення аналітичних робіт 3 перевірки кількісних значень показників на несуперечливість, безпеку і ефективність. У разі якщо показники не відповідають зазначеним вимогам, слід здійснити їх коригування.

$\mathrm{X}$ Етап. Формування та затвердження системи цілей соціально-економічного розвитку регіону. На даному етапі остаточно формується система стратегічних цілей соціально-економічного розвитку регіону, описаних в якісному і кількісному вираженні.

Висновки 3 проведеного дослідження. Ключовим етапом формування цілей регіонального розвитку $\epsilon$ розробка системи стратегічних цільових установок соціально-економічного розвитку регіону. Принципове значення має, на думку автора, визначення вихідних даних (інформаційного забезпечення) для формування цільових установок соціального, екологічного, 


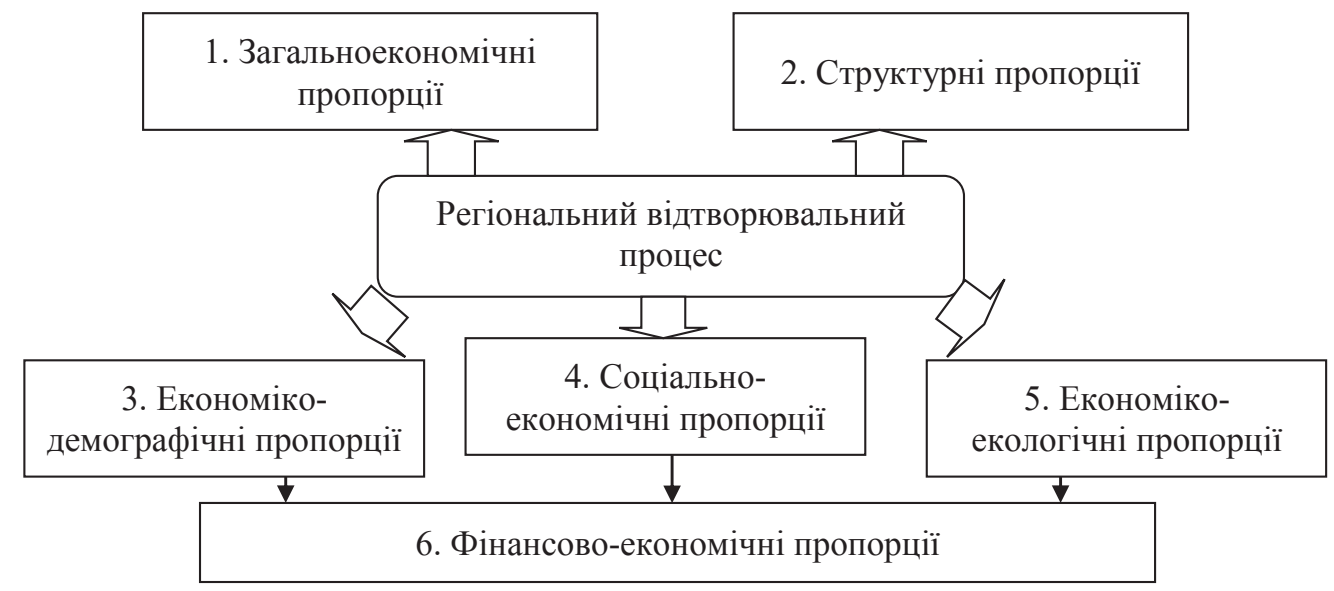

Рис. 3. Класифікація пропорцій регіонального відтворювального процесу в аспекті конкурентоспроможного розвитку

\begin{tabular}{|c|l|}
\hline 1 & $\begin{array}{l}\text { Виявлення і змістовна трактування чинників, що характеризують зміни } \\
\text { основних структурних складових регіону як системи, перевищення } \\
\text { порогових значень яких може привести регіон на траєкторію розвитку, } \\
\text { результатом якої є втрата ним системної цілісності }\end{array}$ \\
\hline 2 & $\begin{array}{l}\text { Визначення індикаторів, за допомогою яких можна здійснити кількісну } \\
\text { оцінку зазначених вище факторів }\end{array}$ \\
\hline 3 & $\begin{array}{l}\text { Розробка науково обгрунтовані рекомендації щодо визначення порогових } \\
\text { значень факторних показників, перевищення яких може виявитися } \\
\text { критичним для регіону з позиції забезпечення його безпечного розвитку }\end{array}$ \\
\hline
\end{tabular}

Рис. 4. Послідовність виконання завдання 3 розробки системи порогових значень факторів, перевищення яких критично для безпечного конкурентоспроможного розвитку регіону

економічного розвитку і цільових установок системи управління.

В статі були обгрунтовані вимоги до структури інформаційного забезпечення процесу формування стратегічних цільових установок розвитку регіону в розрізі основних етапів їх розробки. 3 нашої точки зору, сутність механізму реалізації стратегічних цілей розвитку регіону полягає в цілеспрямованому комплексній дії регіональних органів влади та управління спільно 3 іншими зацікавленими суб'єктами управ- ління і господарювання на всі підсистеми регіону (соціальну, екологічну та економічну) для досягнення наміченого результату, а саме якісно нового стану регіональної соціально-економічної системи. Визначено, що структура механізму реалізації стратегічних цілей регіонального розвитку являє собою сукупність принципів, методів і інструментів управлінського впливу, що застосовуються регіональними органами влади і управління для реалізації намічених стратегічних цілей регіонального розвитку.

\section{Список використаних джерел:}

1. Геєць В.М. Структурні зміни та економічний розвиток України : монографія. Київ : Ін-т економіки та прогнозув., 2011. 696 с.

2. Качний О.С. Зарубіжний досвід формування механізмів державного управління соціально-економічним розвитком регіонів. Публічне управління та митне адміністрування. 2017. № 2. С. 170-174.

3. Манн Н.В. Ключова спрямованість розвитку регіонального менеджменту - процеси соціалізації. ДонДУУ: Менеджер. 2014. № 1 (67). С. 143-149.

4. Грищенко I.M. Зарубіжний досвід управління регіональним розвитком. Державне управління: удосконалення та розвиток. 2018. №5. URL: http://www.dy.nayka.com.ua/pdf/5_2018/5.pdf.

5. Кліяненко Б.Т., Осика О.П. Соціально-економічний розвиток господарського комплексу регіону: методика 1 практика аналізу. Луганськ : Вид-во СНУ ім. В. Даля, 2008. 227 с. 
6. Жихор О.Б., Кузьминчук Н.В. Модель державного регулювання розвитку регіону: стратегічні, тактичні та операційні напрями. Вісник Університету банківської справи Національного банку України. 2013. № 1(16). С. $21-25$.

7. Територіальний розвиток і регіональна політика в Україні: виклики та пріоритети сталого ендогенного зростання регіонів України в умовах сучасних реформ / наук. ред. В.С. Кравців. Львів, 2018. 157 с.

8. Про затвердження Державної стратегії регіонального розвитку на період до 2020 року. Постанова Кабінету Міністрів України від 6 серпня 2014 р. № 385. Офіиійний вісник Украӥни. 2014. № 70. С. 23.

9. Нова регіональна політика для нової України: аналіт. доп. / за заг. ред. Я.А. Жаліла. Київ : Ін-т сусп.-екон. дослідж., 2017. 76 с.

\section{References:}

1. Geets V.M. (2011) Strukturni zminy ta ekonomichnyy rozvytok Ukrayiny [Structural changes and economic development of Ukraine: monograph]. Kyiv: Institute of Economics and Forecasting, 696 p. (in Ukrainian)

2. Kachnyi O.S. (2017) Zarubizhnyi dosvid formuvannia mekhanizmiv derzhavnoho upravlinnia sotsialnoekonomichnym rozvytkom rehioniv [Foreign experience in forming mechanisms of state management of socio-economic development of regions]. Publichne upravlinnia ta mytne administruvannia, no. 2, pp. 170-174. (in Ukrainian)

3. Mann N.W. (2014) Klyuchova spryamovanist' rozvytku rehional'noho menedzhmentu - protsesy sotsializatsi [The key direction of regional management development is the processes of socialization]. DonSU: Manager, no. 1(67), pp. 143-149.

4. Hryshchenko I.M. (2018) Zarubizhnyi dosvid upravlinnia rehionalnym rozvytkom [Foreign experience in regional development management]. Derzhavne upravlinnia: udoskonalennia ta rozvytok, no. 5. Available at: http://www.dy.nayka.com.ua/pdf/5_2018/5.pdf (in Ukrainian)

5. Klianenko B.T., Osyka O.P. (2013) Sotsial'no-ekonomichnyy rozvytok hospodars'koho kompleksu rehionu: metodyka i praktyka analizu [Socio-economic development of the economic complex of the region: methods and practice of analysis]. Luhansk: SNU Publishing House. V. Dalya, 227 p. (in Ukrainian)

6. Zhikhor O.B., Kuzminchuk N.V. (2013) Model' derzhavnoho rehulyuvannya rozvytku rehionu: stratehichni, taktychni ta operatsiyni napryamy [Model of state regulation of regional development: strategic, tactical and operational areas]. Bulletin of the University of Banking of the National Bank of Ukraine, no. 1(16), pp. 21-25. (in Ukrainian)

7. Kravtsiv V.S. (2018) Terytorialnyi rozvytok i rehionalna polityka v Ukraini: vyklyky ta priorytety staloho endohennoho zrostannia rehioniv Ukrainy v umovakh suchasnykh reform [Territorial development and regional policy in Ukraine: challenges and priorities of sustainable endogenous growth of the regions of Ukraine in the context of modern reforms]. Lviv, 157 p. (in Ukrainian)

8. Pro zatverdzhennia Derzhavnoi stratehii rehionalnoho rozvytku na period do 2020 roku. Postanova Kabinetu Ministriv Ukrainy vid 6 serpnia 2014 r. № 385. Ofitsiinyi visnyk Ukrainy. 2014. No. 70. P. 23.

9. Zhalilo Ya.A. (2017) Nova rehionalna polityka dlia novoi Ukrainy: analit. dop. [New regional policy for the new Ukraine: an analyst. ext.]. Kyiv: In-t susp.-ekon. doslidzh., 76 p. (in Ukrainian) 